\title{
Western Blot Analysis of the IgG-Antibody Response to Acid- Glycine-Extracted Antigens from Campylobacter fetus subsp. fetus and $C$. jejuni in Naturally Infected Sheep
}

\author{
K. GÜRTÜRK ${ }^{1}$, I. H. EKIN ${ }^{1}$, A. ARSLAN ${ }^{2}$ \\ ${ }^{1}$ Department of Microbiology, Veterinary Medicine, University of Yüzüncü Yil, Van, Turkey \\ ${ }^{2}$ Institute for Health Science, University of Yüzüncü Yil, Van, Turkey \\ Received July 28, 2005 \\ Accepted March 13, 2007
}

\begin{abstract}
Gürtürk K., I. H. Ekin, A. Arslan: Western Blot Analysis of the IgG-Antibody Response to Acid-Glycine-Extracted Antigens from Campylobacter fetus subsp. fetus and C. jejuni in Naturally Infected Sheep. Acta Vet. Brno 2007, 76: 245-251.

IgG-antibody response in aborting sheep and in apparently healthy sheep in a flock against acidglycine-extracted antigens from three strains for each $C$. fetus subsp. fetus and $C$. jejuni were analysed by Western blot. One strain of $C$. fetus subsp. fetus was isolated from aborting sheep. Western blot analysis of the sera revealed the presence of IgG antibody binding to the common antigens including proteins with the Mw of $63 \mathrm{kDa}$ and $54 \mathrm{kDa}$ in extracts from both C. fetus subsp. fetus and $C$. jejuni strains. In addition, IgG antibodies in sera from aborting sheep reacted more strongly with the antigens from $C$. fetus subsp. fetus strains with Mw of approximately 100, 95 and $86.5 \mathrm{kDa}$ than those of apparently healthy sheep. The binding profile of the antibodies with these antigens appeared to be unique for each $C$. fetus subsp. fetus strain. On the other hand, IgG antibodies only in sera from aborting sheep recognized strongly the antigens of each C.fetus subsp. fetus strain at the Mw ranged from approximately 26 to $22 \mathrm{kDa}$. However, the antigenic components between 26 and $22 \mathrm{kDa}$ were not detectable in coomassie blue stained gel and thought to have non-protein nature. These low molecular weight antigens of $C$. fetus subsp. fetus may be related to a recent infection in aborting sheep. These observations indicate that such speciesspecific antigens or conjugated protein antigens could be used for improving the specificity of the serological tests to detect $C$. fetus antibodies in sheep sera, and may be the candidates for subunit vaccines against ovine abortion.
\end{abstract}

Ovine abortion, Western blot, C. fetus subsp. fetus, C. jejuni

Various campylobacter species are found in the reproductive organs, intestinal tracts and oral cavities of both animals and humans. C. fetus subsp. fetus is well known as a pathogen causing sporadic or epizootic abortions in sheep and cattle as well as systemic infections in humans. Considerable economical losses in animal production may ensue. C. jejuni, a human pathogen, is also recognized as a cause of abortions in sheep (Blobel and Schliesser 1982). Sheep aborting due to campylobacter infection produce high titres of serum antibodies in the response to these organisms. As for detecting humoral antibody response, several serological tests, such as agglutination, complement fixation, enzyme immunoassay have been reported (Rautelin and Kosunen 1983; Gröhn and Genigeorgies 1985; Melby 1987; Gürtürk et al. 2002). But the use of these tests is limited due to low sensitivity and specificity for the diagnosis of campylobacter infections in sheep. Since effective use of serological tests is mainly related to the specificity of the antigenic or immunogenic components of bacteria used in the tests, the characterization and use of such antigenic components are necessary for enhancing the specificity of the serological tests.

In $C$. fetus infection, a surface layer ( $S$ layer) protein plays an important role in the invasion and survival within the host (McCoy et al. 1975; Blaser and Pei 1993). These proteins 
of $C$. fetus represent a family of high molecular weight proteins including proteins of 98 to 100, 127 and $149 \mathrm{kDa}$ that have been demonstrated by SDS-PAGE and Western blot analysis with rabbit immune sera (Pei et al. 1988; Grogono-Thomas et al. 2000, 2003). Immunoblot studies of $C$. fetus and $C$. jejuni with rabbit and human immune sera showed also that $C$. fetus subsp. fetus, $C$. jejuni and $C$. coli share antigenically cross-reactive epitopes including flagellin with a molecular size of $50 \mathrm{kDa}$ and $61-62 \mathrm{kDa}$ and other major OM proteins (Wenmann et al. 1985). It has been reported that the $31 \mathrm{kDa}$ acid dissociable protein is the antigenic determinant common to the thermophilic Campylobacters but the 92.5 kDa protein of thermophilic campylobacters might be strain-specific (Logan and Trust 1983; Jin and Penner 1988; Dubreuil et al. 1990a).

However, there is little information on the issue, whether these membrane antigens characterized with rabbit immune sera were also recognized with antibodies elicited after natural infection in sheep.

In consideration of the aspect that immune response of sheep against determined antigens after natural infection could be different than those of rabbits, the demonstration of antibodies to the campylobacter antigens with immune sera after natural infection in a compromised animal would give more appropriate information on the membrane antigens implicating in serological tests. This would make it possible not only to improve the specificity of serological tests to be used for the diagnosis of campylobacter infection in sheep, but also to develop strategies for immune protection. Our previous study (Gürtürk et al. 2002) showed also that campylobacter antibodies in sheep sera could be detected with a dot-immunobinding assay and a complement fixation tests by using crude extract of acid dissociable antigens from both $C$. fetus subsp. fetus and $C$. jejuni but the tests failed to discriminate antibodies to the antigens from both campylobacter species. In the present study, therefore, ovine-IgG antibody response to acid-glycine-extracted antigens from $C$. fetus subsp. fetus and C. jejuni strains was analysed to observe possible strain or speciesspecific antigens reacting with IgG antibodies elicited during ovine abortion.

\section{Materials and Methods}

Serum samples

Three sera from different sheep aborting due to $C$. fetus subsp. fetus infection in a flock were used. Sera were obtained 3 or 4 weeks after abortion. C. fetus subsp. fetus was isolated from one of the aborted fetus examined bacteriologically. Additionally three sera were collected from apparently healthy sheep in the same flock which were found to be negative in intestinal culture for Campylobacter. All sera from aborting sheep showed positive antibody titres of 1:20 $\leq$ in complement fixation test (CFT). Sera from apparently healthy sheep had antibody titres of $1: 5 \geq$ in CFT. In CFT, the adapted micro technique (Kolmer method) using cold fixation was employed as described previously (Gürtürk et al. 2002). All sera were found to be negative for antibodies to Brucellae with Rose bengal plate test and Dot-ELISA and the tests were performed as described previously (Gürtürk et al. 1997).

Bacterial strains

The following Campylobacter strains were used in this study: C. fetus subsp. fetus strain F5 was isolated from aborting sheep (of which homolog serum was also used); C. fetus subsp.fetus strain F3; C. fetus subsp. fetus strain F6; $C$. jejuni strain $\mathrm{J} 1$ and $C$. jejuni strain $\mathrm{J} 3$ were isolated from the contents of intestines or gall-bladders of apparently healthy sheep. C. jejuni subsp. jejuni DSM 4688 was supplied from DSM (Braunschweig, Germany).

The $C$. fetus subsp. fetus strains were resistant to nalidixic acid and grew at $25^{\circ} \mathrm{C}$. The C. jejuni strains were sensitive to nalidixic acid, hydrolysed Na-hippurate and grew at $43^{\circ} \mathrm{C}$ but not $25^{\circ} \mathrm{C}$. Both strains could be cultured on the Skirrow's selective medium in a microaerobic atmosphere. They were catalase- and oxidase-positive, Gram negative bacteria with a typical $\mathrm{S}$ form. Both species were identified by further biochemical characteristics as described previously (Holt et al. 1984).

\section{Extraction of antigen}

The antigen was extracted separately from all campylobacter strains and used in Western blot. The bacteria were cultured on Blood agar base (Oxoid No. 2) supplemented with 7\% defibrinated sheep blood and Skirrow's selective supplement for $48-72 \mathrm{~h}$ at $37^{\circ} \mathrm{C}$ and $42^{\circ} \mathrm{C}$, respectively.

Acid glycine extraction was performed after the method described by McCoy et al. (1975). The cultures were harvested into distilled water, washed twice and then suspended in $0.2 \mathrm{M}$ glycine-hydrochloride, $\mathrm{pH} 2.2$ ( $1 \mathrm{~g}$ of cell per $25 \mathrm{ml}$ ). The suspension was stirred at room temperature (RT) for $30 \mathrm{~min}$ and whole cells were removed by 
centrifugation at $10,000 \mathrm{~g}$ for $15 \mathrm{~min}$. The supernatant was neutralized with $\mathrm{NaOH}$ and lyophilised. Protein contents of the extracts were determined by using a protein detection kit (Sigma, St. Louis, OM, USA).

Sodium dodecyl sulphate - polyacrylamide gel electrophoresis (SDS-PAGE) and Western blotting

Glycine extracted proteins were analyzed by SDS-PAGE according to the method of Laemmli (1970) with a $4 \%$ stacking gel and a 10\% running gel. Extracts were mixed with a reducing buffer containing $125 \mathrm{mM}$ Tris, $4 \%$ SDS, $20 \%$ Glycerol and $10 \%$ mercaptoethanol ( $\mathrm{pH}$ 6.8) and boiled for $90 \mathrm{sec}$. Approximately $30-50 \mu \mathrm{g}$ of protein from each glycine extracts was applied per lane and electrophoresis was conducted under a constant current (30 mA per gel) at RT with a Hoefer electrophoresis apparatus (Hoefer Scientific Instruments, USA) and $25 \mathrm{mM}$ Tris-192 mM Glycine buffer ( $\mathrm{pH}$ 8.3) containing 0.1\% SDS. The molecular weight marker (Sigma, St. Louis, OM, USA) contained aprotinin $(6.5 \mathrm{kDa}), \alpha$-lactalbumin $(14.2 \mathrm{kDa})$, trypsin inhibitor $(20 \mathrm{kDa})$, trypsinogen $(24 \mathrm{kDa})$, carbonic anhydrase $(29 \mathrm{kDa})$, glyceraldehyde-3-phosphate dehydrogenase (36 kDa), ovalbumin (45 kDa) and albumin $(66 \mathrm{kDa})$. Gels were stained with $0.025 \%$ coomassie brilliant blue R-250 dye in $40 \%$ methanol, fixed in $50 \%$ methanol-10\% acetic acid and destained in several changes of 5\% methanol-7\% acetic acid.

After electrophoresis, proteins were immediately transferred from slab gel to nitrocellulose paper (BA85; Schleicher \& Schuell, Germany) by the method of Tow bin et al. (1979). Electrophoretic transfer was carried out overnight at 50-60 V with a Hoefer Transblot apparatus (Hoefer Scientific Instruments, USA) and $25 \mathrm{mM}$ Tris$192 \mathrm{mM}$ glycine buffer ( $\mathrm{pH}$ 8.3) containing 20\% methanol. For the immunological detection, the nitrocellulose paper was incubated with $10 \mathrm{mM}$ Tris- $0.9 \% \mathrm{NaCl}$ buffer (TBS, $\mathrm{pH} 7.4$ ) containing $5 \%$ skimmed milk powder for $2 \mathrm{~h}$ at RT to block non-specific binding. The nitrocellulose paper was then incubated with sera diluted 1 in 100 or more with TBS containing $0.05 \%$ Tween 20 (TBS-T) for $2 \mathrm{~h}$ at RT. The nitrocellulose paper was washed three times with TBS-T and incubated with horseradish peroxidase-conjugated donkey anti-sheep immunoglobulin G (whole molecule; Sigma, St. Louis, MO, USA) diluted 1 in 1000 with PBS-T for $2 \mathrm{~h}$ at RT. After washing with PBS-T, the binding was revealed by the treatment of the nitrocellulose paper with 4-chloro-1-naphtol/hydrogen peroxide substrate in TBS.

\section{Results}

\section{SDS-PAGE}

Protein band profile of acid-glycine extracts from C. fetus subsp. fetus and C.jejuni strains in coomassie blue-stained polyacrylamide gel ranged in molecular weight from $22 \mathrm{kDa}$ to greater than $100 \mathrm{kDa}$ in this gel system (Fig. 1, Plate VIII). Protein bands with the Mw of approximately $63 \mathrm{kDa}$ and $54 \mathrm{kDa}$ were present in each extract from both $C$. fetus subsp. fetus and $C$. jejuni strains, whereas several protein bands including those with Mw of approximately 42.4 to $46.5,36,30,26$ and $22 \mathrm{kDa}$ could only be observed in the extracts from $C$.fetus subsp. fetus strains. The protein bands of $C$. fetus subsp.fetus strains at the Mw of approximately $113.4,100,95,86.5 \mathrm{kDa}$ appeared to be unique for each strain, but they were not observed in $C$. jejuni strains.

\section{Western Blotting}

Immunoblotting analysis of the sera from aborting sheep and from apparently healthy sheep with the glycine extracted antigens from $C$. fetus subsp. fetus and C. jejuni strains are shown in Figs 2 and 3 (Plate VIII and IX). IgG antibodies in each serum reacted with the common protein antigens of approximately $63 \mathrm{kDa}$ and $54 \mathrm{kDa}$ from all strains of C. fetus subsp. fetus and $C$. jejuni. In addition, all sera showed similar binding profile with the antigens from $C$. fetus subsp. fetus isolated from aborting sheep which were still distinctly different from those of $C$. jejuni DSM 4688 (Fig. 2). However, the IgG antibodies from aborting sheep sera reacted strongly with the antigens from infecting strain of $C$. fetus subsp. fetus in the Mw region from approximately 26 to $22 \mathrm{kDa}$. On the other hand, any comparable binding profiles of IgG antibodies in sera from apparently healthy sheep with these antigens were not observed (Fig. 2, panel a). Even if the sera were used at a lower dilution (1:100), the same result was obtained (data not shown). Antibodies in sera from aborting sheep recognized also these low molecular weight antigens in each extract from other strains of $C$. fetus subsp. fetus as well as from homolog infecting strain of $C$. fetus subsp. fetus. Any comparable binding of antibodies to the antigens from $C$. jejuni strains between these molecular weights was not observed (Fig. 3, panel 1). However, antigenic components of $C$. fetus subsp. fetus strains between the molecular weights of 26 to $22 \mathrm{kDa}$ were not observed in coomassie blue stained gel (Fig. 1, lanes a, b, c) 
As represented in Fig. 3, IgG antibodies in serum from aborting sheep reacted also strongly by binding activity with the antigens from other $C$. fetus subsp. fetus strains as well as homolog infecting strain of $C$. fetus subsp. fetus, including the proteins with the molecular weights of approximately 100,95 and $86.5 \mathrm{kDa}$, but the binding profile of the antibodies with these antigens appeared to be unique for each strain. Any comparable binding of the antibodies with the antigens from all $C$. jejuni strains at the range of these Mw could not be observed (Fig. 3, panel 1). Antibodies in serum from apparently healthy sheep reacted weakly with the antigens of $C$. fetus subsp. fetus strains, excepting the $63 \mathrm{kDa}$ and $54 \mathrm{kDa}$ (Fig. 3, panel 2) but no reaction was apparent in Western blots when higher dilutions of serum was used (Plate IX, Fig. 4, panel a, 1 - 2). However, the binding profile of the antibodies in serum from apparently healthy sheep with the antigens from $C$. jejuni strains did not differ from those of aborting sheep (Fig. 3, panel 1 - 2) and remained still undistinguishable, even if a higher dilution of the serum was used (Fig. 4, panel b, 1 - 2).

\section{Discussion}

Studies on immunogenicity of $C$. jejuni and $C$. fetus cellular components during human infection have been well reported. Sera from rabbits immunized with $C$. jejuni reacted with a number of components in outer-membrane protein preparations and differed from human sera (Nachamkin and Hart 1985). Recently, an investigation has been reported on the role of S layer protein (SLP) during C. fetus infection in sheep (Grogono-Thomas et al. 2000). Different isotypes of antibodies directed against SLPs during ovine infection were also demonstrated with enzyme-immunoassay (Grogono-Thomas et al. 2003). A number of specific outer membrane antigens of $C$. fetus and $C$. jejuni are well characterized by immunoblot with rabbit immune sera (Wenmann et al. 1985). However, data on immunoblot analysis of antibody response of naturally infected sheep against these SLPs or other antigenic components of $C$. fetus are not available.

C. fetus is known to be the most common agent of ovine abortion, but the specificity of serological tests for the diagnosis of $C$. fetus infection was limited due to cross-reactivity of the antibodies with the glycine extracted antigens from both $C$. fetus and $C$. jejuni. Glycine extracted antigens from $C$. jejuni were found to be a mixture of different proteins, including flagella antigens and acid dissociable surface antigens. The $62-63 \mathrm{kDa}$ proteins confirmed as the flagellum were antigenically cross reactive with thermophilic campylobacters and C. fetus (Logan and Trust 1983; Mills et al. 1986). The $31 \mathrm{kDa}$ acid dissociable protein appeared to be an antigenic determinant common to the thermophilic campylobacters (Dubreuil et al. 1990). A $92.5 \mathrm{kDa}$ protein was shown to be a strain-specific antigen in C. jejuni (Jin and Penner 1988).

In the present study, Western blot analysis of the sera from both aborting and apparently healthy sheep revealed similar binding patterns with the antigens from both $C$. fetus subsp. fetus (isolated from the aborting sheep) and C. jejuni, including approximately 63 and $54 \mathrm{kDa}$ proteins which were one of the major proteins in coomassie blue stained gel. The $63 \mathrm{kDa}$ antigens, that were thought to be components of flagellin, appeared to be major proteins involved in the cross reactivity of the sera with antigens from both $C$. fetus and $C$. jejuni strains. The $54 \mathrm{kDa}$ antigen might be other acid dissociable surface protein or a breakdown product of $63 \mathrm{kDa}$ protein. Similar to our results, Wenmann et al. (1985) reported that $C$. fetus shares only two antigens strongly with $C$. jejuni and $C$. coli, proteins with molecular weights of 62 and $50 \mathrm{kDa}$ reacting with rabbit immune sera to $C$. jejuni in Western blots. Our Western blot studies showed also that the binding profile of antibodies in sheep sera with the glycine extracted antigens from C. fetus subsp. fetus, except for 63 and $54 \mathrm{kDa}$ antigens, were found to be different from those of C. jejuni. C. fetus subsp. fetus and C. jejuni differed also by their protein band profile in coomassie blue stained gel. Therefore, 
antibodies in sheep sera did not appear to cross-react with other antigens of both Campylobacter species, excepting $63 \mathrm{kDa}-54 \mathrm{kDa}$ proteins.

Our Western blot studies demonstrated also antibodies in sheep sera against the approximately 100,95 and $86.5 \mathrm{kDa}$ proteins of $C$. fetus strains, but their binding profile with the antigen from each $C$. fetus subsp. fetus strain were found to be unique in both coomassie blue stained gel and in Western blots. These antigens of $C$. fetus could not be detected in extracts from $C$. jejuni and thought to be S layer proteins (SLP). SLP of $C$. fetus serve as important virulence factors in pathogenesis of C. fetus infections (McCoy et al. 1975; Blaser and Pei 1993). These antigens of $C$. fetus, including the high molecular weight proteins of 98 to 100,127 and $149 \mathrm{kDa}$ are present in glycine extracts from $C$. fetus strains and the diversity of size and structure of the SLP of $C$. fetus have been well reported (Pei et al. 1988; Fujimoto et al. 1991; Brooks et al. 2002). Grogono-Thomas et al. (2000) reported also that most $C$. fetus subsp. fetus isolates from natural ovine infections express the $97 \mathrm{kDa}$ protein but the $127 \mathrm{kDa}$ and $149 \mathrm{kDa}$ surface layer proteins are rarely seen.

In this study, antibodies in aborting sheep reacted strongly with the high molecular weight antigens of $C$. fetus, even if higher dilutions of serum were used. Although antibodies against C. fetus antigens with high molecular weights were also present in sera from apparently healthy sheep, they were not detectable in higher dilutions of sera. These results indicate that the antibodies in sera from apparently healthy sheep could be acquired during a past $C$. fetus infection and sheep aborting recently due to $C$. fetus infection could have developed a substantial systemic antibody response directed against antigens with high molecular weight.

Dubreuil et al. (1990b) reported that the acid dissociable protein with low molecular weight, e.g. $31 \mathrm{kDa}$ protein, appeared to be an antigenic determinant that is common to the thermophilic campylobacter strains, but not in C. fetus subsp. fetus. In our study, Western blots of the sera from aborting sheep, but not from apparently healthy sheep, demonstrated a distinctly different reaction with the antigenic components of $C$. fetus subsp. fetus strains between the molecular weights of approximately 26 to $22 \mathrm{kDa}$. However, except for the proteins with the molecular weight of approximately 26 to $22 \mathrm{kDa}$, other antigenic components reacting in this region of Western blots could not be observed in coomassie blue stained gel and appeared to be of a non-protein nature. These antigens of $C$. fetus appeared not to be present in $C$. jejuni strains and may be species-specific. The role of these antigenic components of $C$. fetus during ovine abortion are not known but may be related to a recent infection in aborting sheep. Further studies are necessary for the purification and characterization of such antigenic components of $C$. fetus subsp. fetus.

In conclusion, the results of this study showed that the acid glycine extractable proteins of both $C$. fetus subsp. fetus and $C$. jejuni with the Mw of approximately $63 \mathrm{kDa}$ and $54 \mathrm{kDa}$ were dominant antigens involved in cross-reaction with the IgG antibodies in sheep sera. IgG antibody response in aborting sheep were mainly directed against the high molecular weight antigens of $C$. fetus subsp. fetus of which binding profile were unique for each strain and were stronger than those in apparently healthy sheep. We have also demonstrated antibodies only in aborting sheep to a group of acid-glycine extractable antigens of $C$. fetus subsp. fetus of $\mathrm{Mw}$ ranging from approximately 26 to $22 \mathrm{kDa}$ which may be related to a recent infection in aborting sheep. Such species-specific antigens could be used for improving the specificity of serological tests to detect anti-C. fetus antibodies in sheep, and may be candidates for subunit vaccines against ovine abortion due to $C$. fetus infection.

\section{Analýza IgG protilátkové odpovědi na antigeny Campylobacter fetus subsp. fetus $a C$. jejuni extrahované acid-glycinem pomocí metody Western blot u přirozeně infikovaných ovcí}

Pomocí Western blotu byla analyzována IgG protilátková odpověd’ u abortujících a zdra- 
vých ovcí ve stádě na acid-glycinem extrahované antigeny ze tří kmenů pro každý $C$. fetus subsp. fetus a $C$. jejuni. Jeden kmen $C$. fetus subsp. fetus byl izolován z abortující ovce. Western blot séra odhalil přítomnost IgG protilátek vázajících se na běžné antigeny včetně proteinů s Mr 63 kDa a 54 kDa v pasážích z kmenů $C$. fetus subsp. fetus a $C$. jejuni. Navíc protilátky IgG ze séra abortující ovce, oproti těm ze zdravých ovcí, reagovaly výrazně více s antigeny kmenů $C$. fetus subsp. fetus o Mr přibližně 100,95 a 86.5 kDa. Profil vázajících se protilátek s těmito antigeny se zdá být unikátní pro každý kmen $C$. fetus subsp. fetus. Na druhou stranu jen protilátky ze séra abortující ovce dobře rozpoznaly antigeny každého kmene $C$. fetus subsp. fetus o Mr od asi 26 do $22 \mathrm{kDa}$. Antigenní komponenty s Mr 26 až 22 kDa nebylo možné detekovat v gelu barveném koloidní coomassie blue. Má se za to, že jsou neproteinové povahy. Tyto antigeny $C$. fetus subsp. fetus s nízkou molekulovou hmotností mohou souviset s nedávnou infekcí abortující ovce. Tato zjištění naznačují, že takto druhově specifické antigeny nebo antigeny konjugovaných proteinů mohou být využívány ke zlepšení specificity sérologických testů při detekci protilátek $C$. fetus v séru ovcí, a mohly by být i kandidáty pro subjednotkové vakcíny proti abortům ovcí.

\section{Acknowledgement}

We are thankful to the Presidency for Scientific Research Projects of University of Yuzuncu Yil for the support of this study (Project No: 02.VF.006).

\section{References}

BLASER MJ, PEI Z 1993: Pathogenesis of Campylobacter fetus infections: critical role of high-molecular-weight S-layer proteins in virulence. J Infect Dis 167: $372-377$

BLOBEL H, SCHLIESSER T 1982: Handbuch der bakteriellen Infektionen bei Tieren. VEB Gustav Fisher Verlag, Jena

BROOKS BW, ROBERTSON RH, LUTZE-WALLACE CL, PFAHLER W 2002: Monoclonal antibodies specific for Campylobacter fetus lipopolysaccharides. Vet Microbiol 87: 37-49

DUBREUIL JD, KOSTRZYNSKA M, LOGAN SM, HARRIS LA, AUSTIN JW, TRUST TJ 1990a: Purification, characterization and localization of a protein antigen shared by thermophilic Campylobacters. J Clin Microbiol 28:1321-1328

DUBREUIL JD, KOSTRZYNSKA M, AUSTIN JW, TRUST TJ 1990b: Antigenic differences among Campylobacter fetus S-Layer proteins. J Bacteriol 172: 5035-5043

FUJIMOTO S, TAKADE A, AMAKO K, BLASER MJ 1991: Correlation between molecular size of the surface array protein and morphology and antigenicity of the Campylobacter fetus S layer. Infect Immun 59: 2017-2022

GROGONO-THOMAS R, DWORKIN J, BLASER MJ, NEWELL DG 2000: Roles of the Surface Layer proteins of Campylobacter fetus subsp. fetus in ovine abortion. Infect Immun 68: 1687-1691

GROGONO-THOMAS R, BLASER MJ, AHMADI M, NEWELL DG 2003: Roles of the S-Layer protein antigenic diversity in the immune response of sheep experimentally challenged with Campylobacterfetus subsp. fetus. Infect Immun 71: 147-154

GRÖHN K, GENIGEORGIES C 1985: Detection of Campylobacter antibodies and its application in seroepidemiological studies in sheep and cattle herds. Acta Vet Scand 26: 30-48

GÜRTÜRK K, EKIN IH, AKSAKAL A, SOLMAZ H 2002: Detection of Campylobacter antibodies in sheep sera by a Dot-ELISA using acid extracts from C. fetus subsp. fetus and C. jejuni strains and comparison with a complement fixation test. J Vet Med B 49: 146-151

GÜRTÜRK K, ILHAN Z, ERGANIS O 1997: Detection of Brucella antibodies in sheep sera using dotimmunobinding assay and rose bengal plate agglutination test. Turk J Vet Anim Sci 21: 341-344

HOLT JG, KRIEG NR, SNEATH PHA, STALEY JT, WILLIAMS ST (Eds.) 1994: Bergey's Manual of Determinative Bacteriology. $9^{\text {th }}$ edition. Williams and Wilkins, Baltimore, USA, pp. 527-533

JIN T, PENNER JL 1988: Role of the 92.5 kilodalton outer membrane protein of Campylobacter jejuni in serological reactions. J Clin Microbiol 26: 2480-2483

LAEMMLI UK 1970: Cleavage of structural proteins during the assembly of the head of bacteriophage T4. Nature (London) 227: 680-685

LOGAN SM, TRUST TJ 1983: Molecular identification of surface protein antigens of C. jejuni. Infect Immun 42: 675- 682

McCOY EC, DOYLE D, BURDA K, CORBEIL LB, WINTER AJ 1975: Superficial antigens of Campylobacter (Vibrio) fetus: Characterization of an antiphagocytic component. Infect Immun 11: 517-525

MELBY K 1987: Antibody response in patients infected with Campylobacter jejuni/coli assayed with a complement fixation test and a DIG-ELISA method. NIPH Ann 10: 29-31 
MILLS SD, BRADBURY CW, PENNER JL 1986: Isolation and Characterization of a common antigen in Campylobacter jejuni and Campylobacter coli. J Clin Microbiol 24: 69-75

NACHAMKIN I, HART AM 1985: Western blot analysis of the Human antibody response to Campylobacter jejuni cellular antigens during gastrointestinal infection. J Clin Microbiol 21: 33-38

PEI Z, ELLISON RT, LEVIS RV, BLASER MJ 1988: Purification and characterization of a family of high molecular weight surface proteins from Campylobacter fetus. J Biol Chem 263: 6416-6420

RAUTELIN H, KOSUNEN TU 1983: An acid extract as a common antigen in Campylobacter coli and Campylobacter jejuni strains. J Clin Microbiol 17: 700-701

TOWBIN H, STAEHELLIN T, GORDON J 1979: Electrophoretic transfer of proteins from poliacrylamide gels to nitrocellulose sheet: procedure and some applications. Proc Natl Acad Sci USA 76: 4350-4354

WENMANN MW, CHAI J, LOUIE TJ, GOUDREAU CH, LIOR H, NEWEL DG, PEARSON AD, TAYLOR DE 1985: Antigenic analysis of Campylobacter flagellar protein and other proteins. J Clin Microbiol 21: $108-112$ 


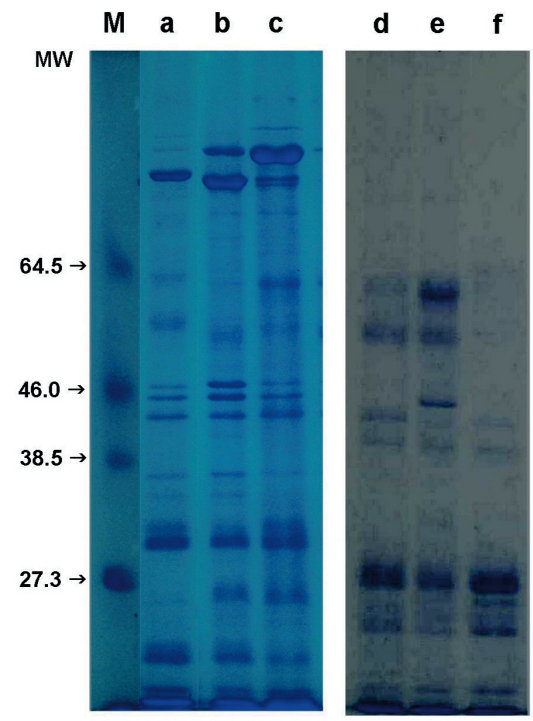

Fig. 1. SDS-PAGE (10\% polyacrylamide) of the glycine extracted components from different C. fetus subsp. fetus (lanes a, b, c) and C. jejuni (lanes d, e, f) strains. Lane b; infected with strain of C. fetus subsp. fetus F5; Lane d; C. jejuni subsp. jejuni DSM 4688. Poliacrylamide gels were stained with Coomassie brilliant blue. Lane M; Molecular weight marker and Molecular weights (MW) are indicated in $\mathrm{kDa}$.
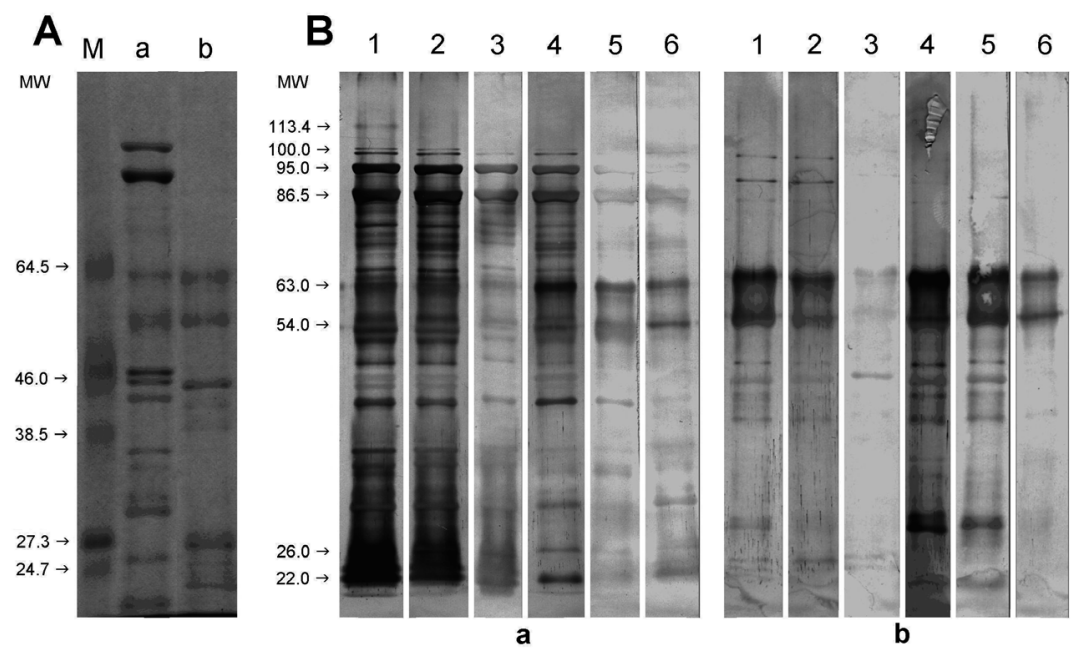

Fig. 2. (A); SDS-PAGE of the glycine extracted proteins of C. fetus subsp. fetus strain F5 (a) and $C$. jejuni subsp. jejuni DSM 4688 (b); Lane M; Molecular weight marker (B);Western blot analysis of sera from aborting sheep $(1,2,3)$ and from apparently healthy sheep $(4,5,6)$ with the glycine extracted antigens of C. fetus subsp. fetus strain F5 (panel a) and C. jejuni subsp. jejuni DSM 4688 (panel b). Homolog serum taken from the aborting sheep from which C. fetus subsp. fetus F5 was isolated, were shown in lane 1. Sera were diluted 1 in 1000. Molecular weights (MW) are indicated in $\mathrm{kDa}$. 
Plate IX

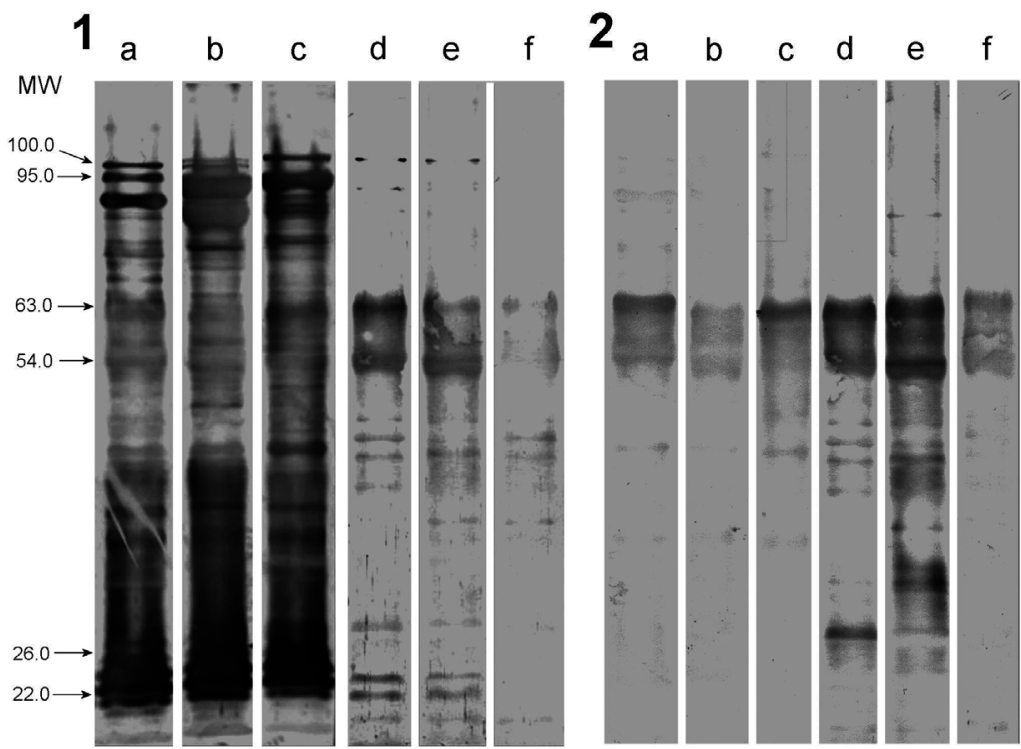

Fig. 3. Western blot analysis of serum from aborting sheep (panel 1) and from apparently healthy sheep (panel 2) with the glycine extracted antigens from different campylobacter strains. Lanes a, b, c; C. fetus subsp. fetus strain F3, F5 (homolog infecting strain), and F6, respectively; Lanes d, e, f; $C$. jejuni subsp. jejuni DSM 4688, C. jejuni strain J1 and J3 respectively. Molecular weights (MW) are indicated in $\mathrm{kDa}$.

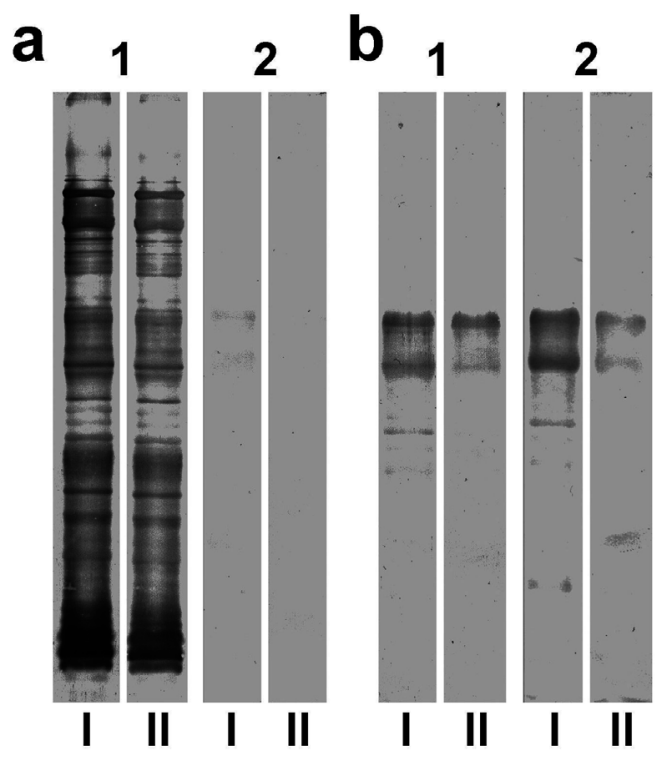

Fig. 4. Western blot analysis of glycine extracted antigens from homolog infecting strain of $C$.fetus subsp. fetus strain F5 (panel a) and C. jejuni subsp. jejuni DSM 4688 (panel b) with the serum from aborting sheep (1) and from apparently healthy sheep (2) diluted 1:2000 (I) and 1:4000 (II). 